\title{
Development of Electronic Module for Description Text Writing Skill Based Contextual Teaching and Learning for Seventh grade student of SMP
}

\author{
H A Gujer ${ }^{1}$ and Afnita ${ }^{2}$ \\ \{holyammiag@gmail.com ${ }^{1}$ \} \\ ${ }^{1}$ Master Program Student, Universitas Negeri Padang, Indonesia \\ ${ }^{2}$ Faculty of language and Art, Universitas Negeri Padang, Padang Indonesia, Indonesia
}

\begin{abstract}
Abstrack. This research was conducted to overcome the limitation of teaching materials in description texts. Students need teaching materials in the form of electronic learning module as one of learning resource for students in grade VII. This study aimed to describe the process of developing electronic module of description text writing skills based on valid contextual teaching and learning (CTL) (seen from the aspect of content, presentation, language, and graphics) and practical (seen from the ease of use and conformity with time). used by students in grade VII of junior high school. The theory used in this research were description text, Contextual Teaching and Learning (CTL), elearning module, and development model. The type of this research was research and development. The development model used was 4-D (defining, designing, developing, and distributing). The subject of this research was the students in grade VII of SMP 12 Padang, which numbered 25 people. The research data consists of qualitative and quantitative data. Qualitative data was collected through filling in e-module validation questionnaire, e-module practicality questionnaire, and student activity observation sheet. Quantitative data was obtained from student learning outcomes in learning to write description text. The results of this study indicated that electronic module for writing description text based on contextual teaching and learning (CTL) which was created is valid, practical, and effective. This can be proved by the results of validity, practicality, and effectiveness of e-modules. E-module validality by experts was obtained based on the value of e-module validity that scored $93.83 \%$ so that e-modules are categorized as a very valid module. The practicality of e-module was obtained based on teacher practicality values which was $84.16 \%$ with practical category and student practicallity was $84.14 \%$ which was categorized as a very practical categorie.
\end{abstract}

Keywords: Text description, module electronic, contextual teaching and learning

\section{Introduction}

Based on the result of an interview on November 14, 2018, with Ms. Misefrita, S.Pd. as a Bahasa's teacher who teaches in grade VII of SMP 12 Padang, it is known that students' ability to write explanatory texts is below average. This can be seen from some student score task which has not met the minimum completeness criteria that have been determined, which is 80 . 
Not only obtained from teacher's interview, but student learning outcomes in writing descriptive text in SMPN 12 Padang is also known by conducting student analysis, teacher analysis, and concept analysis. Based on the analysis of students who have done, there were two aspects which are analyzed, they were learning source and students personality and environment. First, the aspect of learning sources that are used by students is the only a textbook from the government. The book is a compulsory source that must be provided during the learning process. Second, the personality and environment aspects of students. (a) Students are more likely to like a comfortable classroom atmosphere when learning Bahasa. (b) There are $50 \%$ of students who prefer independent learning. This means that students can do writing exercises both independently and in groups.

Based on those aspects, it is necessary to develop e-modules that can attract students to learn and facilitate students in learning. There must be appropriate e-modules with good material, presentation, language, and graphics [1]. Making e-modules aimed to provide references other than textbooks that are distributed by the government. In addition, e-modules can be used by educators or teachers as a reference to make the new e-modules. It is done so that e-modules are designed in accordance with the development of students, their abilities, interests, and needs so that students are interested in writing [2,3,4].

The facts in the field showed that e-modules had a higher value compared to study groups that use textbooks. An online learning environment allows students to explore information from various sources quickly and easily. This will encourage students to learn to be critical and selective in choosing information according to the problems which are given $[5,7,8,9,10]$. Based on this reality, it is important to develop e-modules based on Contextual Teaching and Learning (CTL) writing skills in the description text for students in grade VII of SMP 12 Padang. Learning models that connect subject material with the context of everyday life are certainly needed by students. The development of writing e-modules based on Contextual Teaching and Learning (CTL) is very appropriate because writing activities require material that is close to the environment and daily life of students so that student can be more attractive to write[11,13]. With the presentation of the material and steps of structured activity, it is expected that students will get the concept faster and be able to understand the contents of the description text properly. This e-module is expected to provide solutions for students who have difficulty in writing description texts and to overcome the limitations of the learning resources that teachers have. This e-module is also expected to develop students' creativity and innovation in learning[14,15].

\section{Research and Methods}

The development model used is a 4-D model. The product that is developed in this study is an e-learning module based on contextual teaching and learning. The development of 4-D Emodule consists of four stages of development, namely (a) define, (b) design, (c) develop, and (e) disseminate.

The subject of this e-module is a seventh-grade student of Junior High School in the City of Padang. This study is limited in junior high schools that have used the revised edition of the 2013 curriculum. The school is SMPN 12 Padang. Data from the trials are qualitative and quantitative data. Instruments used consisted of interview sheets, student analysis questionnaires, curriculum analysis questionnaires, concept analysis questionnaires, product validation sheets, e-module practicality sheets, student activity observation sheets, writing performance tests, writing performance test assessment rubrics, and e-module distribution questionnaires. 
The data analysis technique used is descriptive data analysis, that is by describing the validity, practicality, and effectiveness of the e-learning module writing description text based on contextual teaching and learning of eighth-grade students in SMP N 12 Padang. The results of this study were analyzed using descriptive statistics to obtain average and percentage values as detailed information needed. Analysis data of the study was conducted to determine the validity, practicality, and effectiveness of e-modules.

\section{Research Results and Discussion}

\subsection{The definition phase (Define)}

The defining stage consists of five steps, they were the initial analysis, student analysis, task analysis (curriculum analysis, concept analysis, and formulation of objectives). The final preliminary analysis aimed to bring up and determine the basic problems in learning. Student analysis is a study of student characteristics which include ability, knowledge background, and the level of cognitive development of students. Task analysis is a collection of descriptions to determine the contents of teaching material in the form of an outline. Task analysis includes content structure analysis, concept analysis, and formulation of learning objectives. Content structure analysis is a series of descriptions to identify the suitability of the curriculum with the compiled e-modules. Concept analysis is a way to determine the material concepts needed for the preparation of e-modules.

\subsection{Stage design (Design)}

The preparation of e-module begins with finding various references needed. After that, design the outline of the e-module, and design it to have an attractive appearance. The preparation of the e-module framework is adapted to contextual teaching and learning concept. E-modules are designed based on theories about the structure of e-modules, namely introduction, learning activities, and evaluation. The development of the learning activities section in e-modules is divided into two, learning activities 1 is about aspects of knowledge while learning activities 2 is concerning aspects of skills.

\subsection{Development stage (Develop)}

\section{a. Validity test}

The defining and design phase is complete, then the development phase is carried out. Development is carried out to test the draft of e-module that has been prepared. The activities carried out at this stage consist of three, such as (a) validity test, (b) practicality test, and (c) effectiveness test. The first activity is to test the validity of e-modules. Validity test is carried out to determine the level of validity of e-modules that have been designed. The validation process is carried out by experts who are experts in their fields. Based on the results of validation, e-module can be known whether it is valid or not, or feasible to be tested or not on students. After e-module is declared valid, the next activity is to conduct a practicality test. Whereas the effectiveness of e-modules is obtained from learning outcomes (cognitive, psychomotor), then the effectiveness of e-modules is obtained from the value of student attitudes during studying e-modules.

Table 2. Results of the electronic module validation strategist

\begin{tabular}{|l|l|l|l|l|}
\hline No & Rated Aspects & Score & Validity (\%) & Category \\
\hline
\end{tabular}




\begin{tabular}{|l|l|l|l|l|}
\hline 1 & Feasibility of the contents & 87,66 & $87,11 \%$ & Very valid \\
\hline 2 & Language & 32 & $100 \%$ & Very valid \\
\hline 3 & Presentation of e-modules & 96,66 & $96,64 \%$ & Very valid \\
\hline 4 & Graphic & 32 & $91,6 \%$ & Very valid \\
\hline Total & & 248,65 & $93,83 \%$ & Very valid \\
\hline
\end{tabular}

Based on the analysis of the data, it is obtained that the validity of e-module Skilled Writing Text description is $93.83 \%$ with a very valid category. The description of the validity values of each validated aspect is as follows. First, the validation of the feasibility aspect of the e-module content is $87.11 \%$ with a very valid category. Second, the validation of the language aspects of e-modules is $100 \%$ with very valid categories. Third, the validation of the e-module presentation aspect is $96.64 \%$ with a very valid category. Fourth, the validation of the graphic aspects of e-modules is $91.6 \%$ with very valid categories. Test Practicalities The results of teacher and student e-module analysis can be known in the following table.

Table 3. Data Description Practicalities Electronic Module by Teacher

\begin{tabular}{|l|l|l|l|}
\hline No & Rated Value & Practicality Value $(\%)$ & Category \\
\hline 1. & Ease of use & 85,00 & Very practical \\
\hline 2. & Time used & 83,33 & Very practical \\
\hline Overall E-Module Practicality & 84,16 & Very practical \\
\hline \multicolumn{2}{|l}{} & \\
\hline
\end{tabular}

The E-module is filled by practitioners, the practical value is $84.16 \%$ with very practical categories. This value is obtained from the calculation of the score of each practicality indicator. First, the ease of use has a practicality value of $85.00 \%$ with a very practical category. Second, the time used has a value of practicality $83.33 \%$ with a very practical category. For more details, see the following picture.

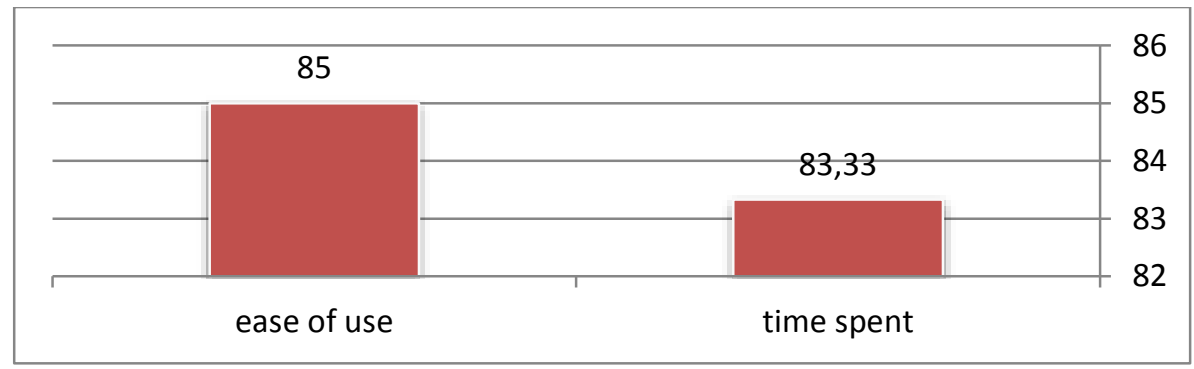

Table 4. Data Description Practicalitas electronic module by Students

\begin{tabular}{|l|l|l|l|}
\hline No & Rated Aspects & Practicality Value (\%) & Category \\
\hline 1. & Ease of use & 85,23 & Very practical \\
\hline 2. & Time used & 82,14 & Very practical \\
\hline Overall E-Module Practicality & 84,14 & Very practical \\
\hline
\end{tabular}

\subsection{Deployment phase (Disseminate)}


The disseminate stage is the final stage of the process of developing e-learning modules for writing description text based on contextual teaching and learning in grade VII of SMP N 12 Padang. The distribution was carried out according to the advice given by the collaborator teacher in the trial class. The distribution of e-modules is conducted in two stages. The first stage is the limited distribution of e-modules to other teachers besides collaborators in the trial class, namely teachers who teach in other classes. The teacher receives one file or one softcopy of e-module. In addition, the teacher was also given a questionnaire about the distribution of e-modules. The second stage of distributing e-modules to students is conducted by sharing e-module files or softcopy to all students in the class.

\section{Conclusion}

Based on the results of the development that has been carried out, the following points can be concluded. First, the process of developing the e-module at the defining stage. At this stage it is concluded that there are several problems that inhibit the achievement of learning objectives in writing description text, it is because the limitations of the teaching materials used. This has an impact on student learning outcomes which the average score is still below the Minimum Completion Criteria (KKM). Second, the process of developing e-modules at the design stage. At this stage, the e-module framework is designed and the e-module draft is arranged. The planning of e-module draft consists of at least learning instructions, competencies to be achieved, contents of the material, exercises, and worksheets. Third, the process of developing e-module at the develop stage. At this stage, e-module that have been created are then validated to see the validity of e-modules. E-module for writing description text based on contextual teaching and learning which is developed is a very valid category. This can be known from the validity of e-module with the acquisition of module which has score 93.83 with very valid categories. The practicality of e-module can be seen from the ease of students and students using the module. Module practicality includes ease of use and time spent. Module practicality by the teacher is $84.16 \%$ with a very practical category. Whereas, the practicality of the module by students is $89.78 \%$, with a very practical category. Fourth, the process of developing e-modules at the dissemination stage (disseminate).

\section{References}

[1] Ibrahim Mohamed Alfaki. (2015). University Students' English Writing Problems: Diagnosis and Remedy. International Journal of English Language Teaching. Published by European Centre for Research Training and Development UK (Www.eajournals.org), 3(3), 40-52.

[2] Buckingham, L. (2008). Development of English Academic Writing Competence by Turkish Scholars. International Journal of Doctoral Studies, 3(2002), 001-018. https://doi.org/10.28945/47

[3] Alodwan, T. A; Ibnian, S. S. (2014). The Effect of Using the Process Approach to Writing on Developing University Students' Essay Writing Skills in EFL Dr. Talal Abd Alhameed Alodwan 1 and Dr. Salem Saleh Khalaf Ibnian 2. International Journal of Linguistic and Communication, 2(2), 147-163.

[4] Chiramanee, T., \& Kulprasit, W. (2014). Journal Writing with Peer Feedback: A Friend or A Foe for EFL Learners. International Journal of English Language Education, 2(2), 142. https://doi.org/10.5296/ijele.v2i2.6038

[5] Muluneh, T. K. (2018). Improving Students' Paragraph Writing Skill through Task- 
Based Approach. Arts and Social Sciences Journal, 9(3). https://doi.org/10.4172/21516200.1000351

[6] Despande, S. (2014). Teaching Writing Skills in English: Involvement of Students in the Assessment and Correction of Their Own Errors. International Journal of English Language Teaching, 3(1), 68-73.

[7] Kurniawati, N.E dan Nuryatin, A. (2006). Developmen of Writing Description Text Modules, 5(1), 48-54.

[8] Lestari, C.D. Development of contextual Modules for Elementary school IPS Subjects. Jurnal Perspektif Ilmu Pendidikan. 30(3), 105-111.

[9] Y. Ning Su, CC Kao, CC Hsu, LCPan, SC Cheng, and YM Huang, "How Does Mozart's music Affectchildren's Reading? The Evidence From learning Anxietyand Reading Rates With E-Books. Educational Technology \& Societ y, vol.20, no. 2.pp.101-112, 2016.

[10] J. Wei Lin and HC Lin, 'User AcceptanceIn A Computer-Supported Collaborative Learning (CSCL) Environment with social network Awarenees (SNA) Support". Australasian Journal of Educational Technology, vol 35, no.1 2018.

[11] T. Doering, L. Pareira, L. Kuechler, and Amherst, "The Use of E-Textbooks In Higher Education: A Case Study, E-Leader Berlin, 2012.

[12] T. Jones and C. Brown, "Reading Engagement: A Comparison Between Tradisional and Ebooks print Books In An Elementary Classroom". International Journal of Intruction, vol 4, no.2. 2011

[13] Pawliczak, Jaana. (2015) Creative writing as a best way to improve writing skiils of students. Sino-Us English Teacing 2015, 12 (5)

[14] B. Plangsorn and S. Poopan, "Development of Prodycing and Using E-Books Competencies of Teachers In Chahhengsao", World Journal on Educational Tecnology, Current Issue, vol.09, no. 02, pp. 112-117, 2017

[15] B.Plangsorn and S. Poopan. "Development Of Producing and Using E-books Competencies Of Teachers In Chachengsao', Word Journal on Educational Tecnology, Current Issues, vol.09, 02, pp. 112-117, 2017.

[16] Sirikham A., \& Sae-Ear, Y. (2014). The development of low cost electronic books for the blind. international Journal of Information and Education Technology, (4) 4.

[17] Trianto, Designing Innovative- Progressive learning model Jakarta: kencana 2012.

[18] Muslim, I. M. (2014). Helping EFL Students Improve their Writing. 4(2), 105-112. 